\title{
A Short Synthesis of a Novel Nucleoside Analog of Fosfomycin
}

\author{
Jae-Min Hwang and Kang-Yeoun Jung* \\ Department of Enironmental \& Applied Chemistry Kangmung National Chiversin, \\ Kangnung-si, Kangwon-do 210-702, Korea \\ Received October 12.2002
}

Key Words : Epoxyphosphonate. Fosfomỵcin analog. Nucleoside epoxỵphosphonate

\begin{abstract}
Various synthetic methods for preparation of 1.2-epoxyalky lphosphonates have been developed since the discovery of the antibiotic fosfomycin [(Z)-(1R 2S)-(-)-1.2-eposypropy 1phosphonic acid] originally isolated from a fermentation broth of Streptomices frodiae in 1969: - Synthesis of fosfomycin analogs is highly attractive due to their potential biological significance. "Many nucleoside and nucleotide derivatives also show antiviral activity so we are interested in the synthesis of noble compounds combining the structure of fosfomycin with a nucleoside. which can possibly show dual biological activities.

During our investigation of fosfomycin analogs we found only a few reported syntheses of 1.2-epoxyalkylphosphonates possessing a sugar ${ }^{+}$or nucleoside component and none of them are similar to the structure of fosfomycin. Therefore. we now report a short synthesis of a new nucleoside epoxyphosphonate from cytidine as a nucleoside analog of fosfomycin.
\end{abstract}

\section{Experimental Section}

General. Methỵlene chloride and $\mathrm{Et}_{3} \mathrm{~N}$ were distilled from $\mathrm{CaH}_{2}$ immediately prior to use. All non-aqueous reactions were conducted in flame-dried glassware under an atmosphere of nitrogen. with magnetic stirring. NMR spectra were obtained on a Bnuker $\mathrm{AC}-300$ spectrometer and recorded at $300 \mathrm{MHz}$ for ${ }^{1} \mathrm{H}\left(75 \mathrm{MHz}\right.$ for ${ }^{13} \mathrm{C}$ ) with $\mathrm{CDCl}_{3}$ as solvent and $\left(\mathrm{CH}_{3}\right)_{4} \mathrm{Si}\left({ }^{1} \mathrm{H}\right)$ or $\mathrm{CDCl}_{3}\left({ }^{13} \mathrm{C} .77 .0 \mathrm{ppm}\right)$ as internal standards unless otherwise noted. All ${ }^{31} \mathrm{P}$ NMR chemical shifts are reported in ppm relative to $85 \% \mathrm{H}_{3} \mathrm{PO}_{4}$ (external standard). High resolution FAB mass spectra were obtained at the University of Iowa Mass Spectrometry Facility

Diethy] [1'-\{5'-hydroxy-6'-(p-toluenesulfony])oxy-2',3'$O$-isopropylidene- $\boldsymbol{\beta}$-D-ribo-hexofuranosyl $;-\mathbf{H}-\mathrm{N}$-acetylcytosyl]-6'-phosphonate $\underline{5}$ : A flame-dried $100 \mathrm{~mL}$ round-bottom flask under $\mathrm{N}_{2}$ was charged with diol \pm ( $350 \mathrm{mg} .0 .71 \mathrm{mmol}$ ) and anhydrous $\mathrm{CH}_{2} \mathrm{Cl}_{2}(14 \mathrm{~mL})$. Freshly distilled triethylamine $(0.25 \mathrm{~mL} .1 .78 \mathrm{mmol}, 2.5 \mathrm{eq}$ ) was then added through a syringe. After the solution was stirred for $5 \mathrm{~min}$ at room temperature. $p$-TsCl (148 mg. 0.78 mmol. 1.1 eq.) was added quickly. The reaction mixture was allowed to stir for 2 days and quenched with distilled water. This aqueous mixture was extracted with $\mathrm{CH}_{2} \mathrm{Cl}_{2}$ and the combined organic

To whom correspondence should be addressed. Phone: +82-33640-2403; Fax: +82-33-640-2244: e-mail: kyjungokangnung.ac.kr extracts were dried over anhydrous $\mathrm{NaSO}_{4}$. After removal of the solvent under reduced pressure. the crude oil was purified by flash column chromatography with a gradient system of methylene clloride and methanol to give the desired product $\underline{\mathbf{5}}(423 \mathrm{mg} .0 .65 \mathrm{~mm} o \mathrm{l} .92 \%)$. ${ }^{\mathrm{l}} \mathrm{H}$ NMR $\delta$ 9.54 (bs. $1 \mathrm{H}$ ). 7.86 (d. $J=8.1 \mathrm{~Hz} .2 \mathrm{H}$ ). 7.64 (d. $J=7.4 \mathrm{~Hz}$. 1H). $7.40(\mathrm{~d} J=7.4 \mathrm{~Hz}, 1 \mathrm{H}), 7.35(\mathrm{~d} . J=8.1 \mathrm{~Hz}, 2 \mathrm{H}) .5 .44$ (d. $J=1.8 \mathrm{~Hz}, 1 \mathrm{H}), 5.16($ dd $J=6.4 .3 .8 \mathrm{~Hz}, 1 \mathrm{H}) .5 .08(\mathrm{~m}$. 2H). 4.62 (d, $J=4.8 \mathrm{~Hz}, 1 \mathrm{H}), 4.43(\mathrm{~m}, 1 \mathrm{H}), 4.26(\mathrm{~m}, 2 \mathrm{H})$. $4.12(\mathrm{~m}, 2 \mathrm{H}), 3.78(\mathrm{dd}, J=8.0 .3 .8 \mathrm{~Hz}, 1 \mathrm{H}) .2 .46$ (s. $3 \mathrm{H})$. 2.27 (s. 3H) 1.40 (s. 3H). 1.31 (m. 9H): ${ }^{13} \mathrm{C}$ NMR $\delta 171.2$ $163.3,154.7,147.1,144.9,133.8,129.5(2 \mathrm{C}), 128.0(2 \mathrm{C})$. $113.8,96.8\left(\mathrm{~d} . J_{C \cdot \mathrm{P}}=7.8 \mathrm{~Hz}\right) .86 .1\left(\mathrm{~d} . J_{C . \mathrm{P}}=9.0 \mathrm{~Hz}\right) .84 .3$, $82.1 .77 .2 .75 .6\left(\mathrm{~d}, J_{C \cdot \mathrm{P}}=166.9 \mathrm{~Hz}\right), 69.7 .64 .5\left(\mathrm{~d}, J_{\mathrm{C} \cdot \mathrm{P}}=7.8\right.$ $\mathrm{Hz}) .63 .1\left(\mathrm{~d}, J_{\text {C.P }}=7.6 \mathrm{~Hz}\right), 27.0 .25 .3 .24 .9 .21 .6,16.3(\mathrm{~d}$. $J_{C \cdot \mathrm{P}}=5.2 \mathrm{~Hz}$ ). $16.2\left(\mathrm{~d}, J_{C \cdot \mathrm{P}}=6.2 \mathrm{~Hz}\right):{ }^{31} \mathrm{P}$ NMR $\delta 17.2$ : HRFABMS calcd for $\mathrm{C}_{26} \mathrm{H}_{37} \mathrm{~N}_{2} \mathrm{O}_{12} \mathrm{PS}(\mathrm{M}+1)^{+} 646.1836$. found 646.1838 .

Diethyl [1'-(5',6'-e]oxy-2',3'- $O$-isopropylidene- $\beta$-D-ribohexofuranosyl)-4- $N$-acetylcytosyl]-6'-phosphonate 6 : An oven dried $50 \mathrm{~mL}$ one-necked round-bottom flask under $\mathrm{N}_{2}$ was charged with tosylate $\underline{\underline{5}}(90 \mathrm{mg} .0 .14 \mathrm{mmol})$ and acetone $(1.5 \mathrm{~mL})$. To this solution was added activated $\mathrm{K}_{2} \mathrm{CO}_{3}$ (58 mg. $0.42 \mathrm{mmol}, 3 \mathrm{eq}$ ). After the mixture was stirred for 2 day's at room temperature. the reaction mixture was filtered and concentrated in vacuo to give the crude product. The oil was purified by column cluromatography with a gradient system of methylene chloride and methanol to give the desired product $\underline{6}(60 \mathrm{mg} .0 .13 \mathrm{mmol}, 91 \%)$. ${ }^{\mathrm{l}} \mathrm{H}$ NMR $\delta 8.87$ (bs. $1 \mathrm{H}$ ). 7.63 (d. $J=7.5 \mathrm{~Hz}, 1 \mathrm{H}$ ). 7.42 (d. $J=$ $7.5 \mathrm{~Hz}, 1 \mathrm{H}) .5 .52(\mathrm{~d} J=1.2 \mathrm{~Hz} .1 \mathrm{H}) .5 .34(\mathrm{~m} .2 \mathrm{H}) .4 .69$ (dd. $J=9.0 .3 .0 \mathrm{~Hz} .1 \mathrm{H}$ ), $4.26(\mathrm{~m}, 4 \mathrm{H}) .3 .72$ (ddd. $J=9.0 .6 .0 .4 .5$ Hz. $1 \mathrm{H}$ ), 3.04 (dd. $J=25.8,4.5 \mathrm{~Hz} .1 \mathrm{H}$ ). 2.34 (s. $3 \mathrm{H}), 1.59$ (s. $3 \mathrm{H}), 1.35(\mathrm{~m}, 9 \mathrm{H}):{ }^{13} \mathrm{C}$ NMR $\delta 170.1,163.2,154.7$, $148.3 .114 .0 .100 .3 .96 .5 .86 .9 .84 .8\left(\mathrm{~d}, J_{C . \mathrm{P}}=3.7 \mathrm{~Hz}\right) .77 .2$. $63.1\left(\mathrm{~d}, J_{C \cdot \mathrm{P}}=6.0 \mathrm{~Hz}\right), 62.8\left(\mathrm{~d} . J_{\mathrm{C} . \mathrm{P}}=6.1 \mathrm{~Hz}\right) .56 .5\left(\mathrm{~d} . J_{C . \mathrm{P}}=\right.$ $1.9 \mathrm{~Hz}), 49.5\left(\mathrm{~d}, J_{C \cdot \mathrm{P}}=202.5 \mathrm{~Hz}\right), 26.9,25.2,25.0,16.5(\mathrm{~d}$ $J_{C \cdot \mathrm{P}}=2.2 \mathrm{~Hz}$ ). $16.4\left(\mathrm{~d}, J_{C \cdot \mathrm{P}}=1.7 \mathrm{~Hz}\right):{ }^{31} \mathrm{P}$ NMR $\delta 17.9$ : HRFABMS calcd for $\mathrm{C}_{19} \mathrm{H}_{29} \mathrm{~N}_{3} \mathrm{O} \varphi \mathrm{P}(\mathrm{M}+1)^{-} 474.1654$, found 474.1641 .

\section{Results and Discussion}

A new nucleoside 5'.6'-epoxyphosphonate 6 was prepared from cytidine using the conditions shown in Scheme 1. As previously reported ${ }^{6}$ diol 4 was prepared from the reaction of 

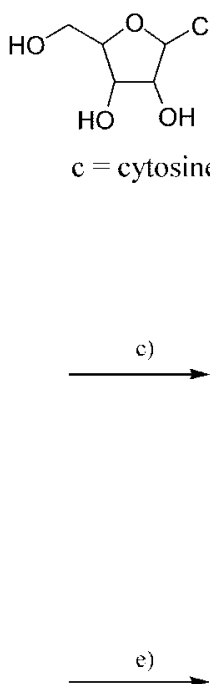

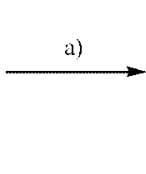

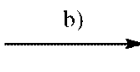

1

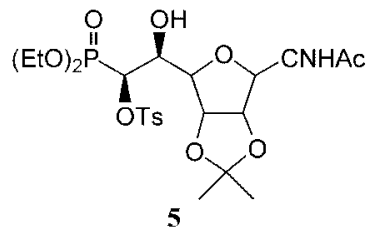

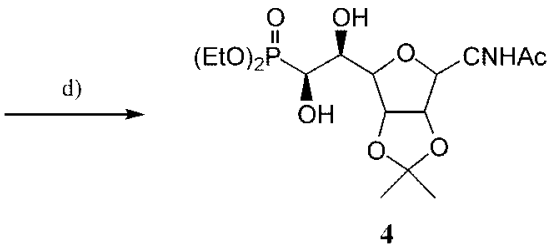
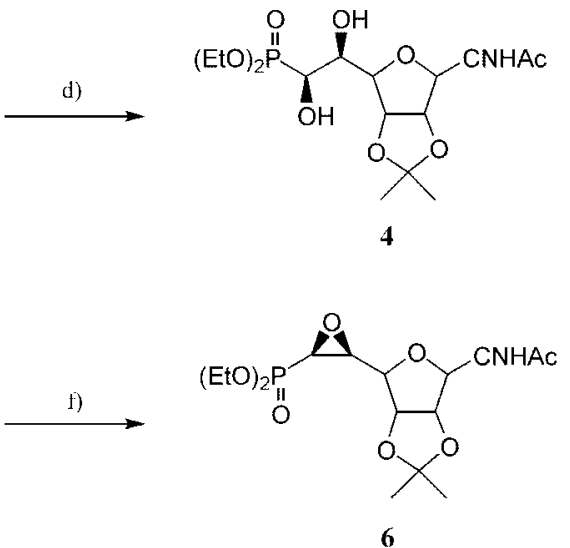

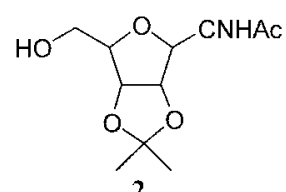

2

6

Scheme 1. (a) $\mathrm{Ac}_{2} \mathrm{O}, \mathrm{CH}_{3} \mathrm{OH}$ (b) $\mathrm{HClO}_{4}, 2,2$-dimethoxypropane, Acetone (c) i. $\mathrm{CrO}_{3}$, Pyridine, $\mathrm{Ac}_{2} \mathrm{O}$, DMF, ii. (EtO) $\mathrm{P}(\mathrm{O}) \mathrm{CH}_{2} \mathrm{PPh} 3$, DMSO. (d) $\mathrm{AD}$ miN- $\alpha$. (e) $p-\mathrm{TsCl}_{3} \mathrm{Et}_{3} \mathrm{~N}, \mathrm{CH}_{2} \mathrm{Cl}_{2}$. (f) $\mathrm{K}_{2} \mathrm{CO}_{3}$, Acetone.
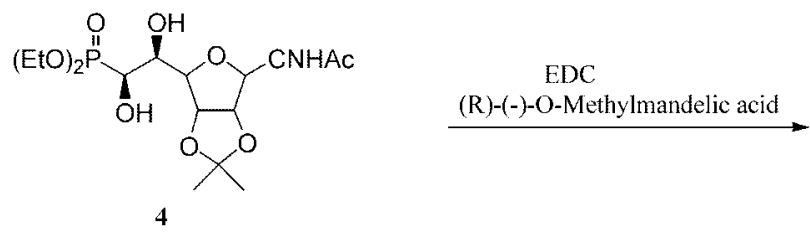<smiles>CCCNCC1OC([C@H](O)[C@@H](O)[PH](=O)OCC)C2OC(C)(C)OC12</smiles>

Figure 1. (R)-Mandelate ester from Diol 4.

the corresponding vinylphosphonate 3 and $\mathrm{AD}$ mix- $\alpha$ in good yield. In order to assign the stereochemistry of diol 4 . mandelate esters were prepared from the reaction of diol 4 . 1-(3-dimethỵlaminopropyl)-3-ethyylcarbodiimide (EDC) with (R)-(-)-O-methylmandelic acid or (S)-(-)-O-methylmandelic acid. The stereochemistry of diol 4 was tentatively assigned as the 5 'S.6'S-diastereomer based on NMR data comparison of $(\mathrm{S})$ and (R)-mandelate esters. 6.7

However. in this study, we were able to confirm the stereochemistry of diol $\dot{4}$ by the crystal structure ${ }^{8.5}$ of the mandelate ester obtained from the reaction of (R)-(-)-Omethylmandelic acid. EDC, and the corresponding diol $t$. (Figure 1 and 2)

With the support of ${ }^{l} \mathrm{H}$ NMR HOMO decoupling studies (Bruker DRX-400) of diol + and tosylate 5. we have assigned each hyddrogen resonance. First. the phosphorus coupled 'H NMR spectrum of diol + showed resonances at $\mathrm{C}_{1}$ (d. at $5.62 \mathrm{ppm}$ ), $\mathrm{C}_{2} \cdot$ (bd. at $5.15 \mathrm{ppm}$. overlapped with $\mathrm{OH}$ on $\left.\mathrm{C}_{5}\right) . \mathrm{C}_{3}(\mathrm{dd}$ at $5.28 \mathrm{ppm}), \mathrm{C}_{4}(\mathrm{dd}$. at $4.39 \mathrm{ppm}) . \mathrm{C}_{5}$ (m. at 4.35 ppm) $\mathrm{C}_{6}$ (overlapped with $\mathrm{CH}_{2}$ on the $\mathrm{P}$. at 4.26 ppm). and $\mathrm{OH}$ on $\mathrm{C}_{6}$ ( $\mathrm{t}$ at $3.99 \mathrm{ppm}$ ). Using this information. HOMO decoupling studies were studies on the possible positions of all the hydrogens. Irradiation of the signal at $C_{3}$ collapsed resonances at $C_{2}$ and $C_{4}$ to give a broad singlet and a doublet respectively. Irradiation of the signal at $C_{3}$ collapsed resonances at $C_{1}$ and $C_{3}$ to give a

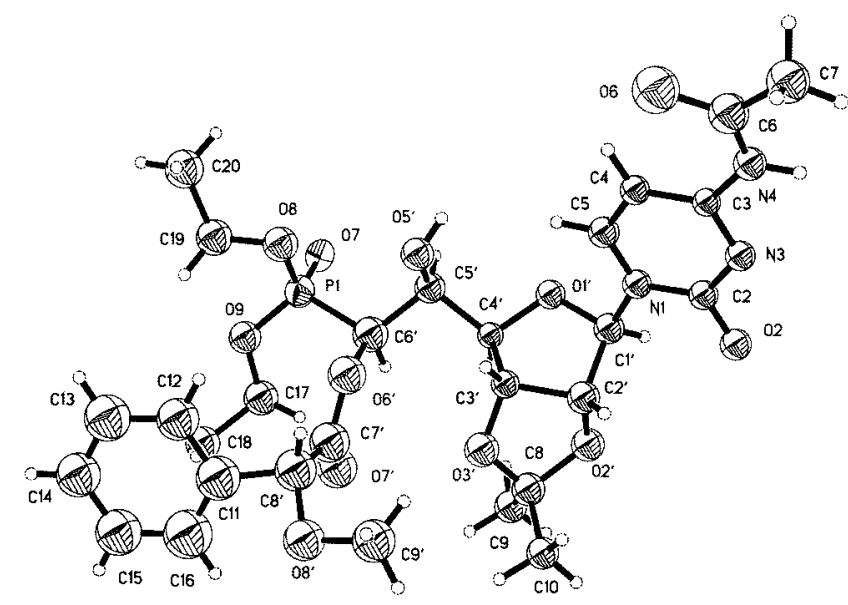

Figure 2. Themal Ellipsoid Drawing of Mandelate Ester of Diol 4 with Atomic Labeling.

singlet and a doublet as expected.

If the resonance for $C_{6}$ overlapped with other signals in the spectrum of diol $\mathbf{4}$, it was assumed that it would shift downfield dramatically if the tosyl group were introduced on the $\mathrm{OH}$ group of $\mathrm{C}_{6}$. due to its deshielding effect.

Based on this assumption and decoupling studies on the 5 'hydroxy'-6'-tosylate $\mathbf{5}$ obtained from regioselective tosylation of diol + with $p$-TsCl ( $p$-toluenesulfonỵl chloride). we were 
able to confirm that the hydrogen peak for $\mathrm{C}_{6}$ shifted from 4.26 to $5.08 \mathrm{ppm}$ (overlapped with $\mathrm{C}_{2}$ ). Irradiation of the resonance at $C_{5} \cdot(4.43 \mathrm{ppm})$ collapsed signals at $C_{4}{ }^{*}$ and $C_{6}$. to give a doublet for $\mathrm{C}_{4}$ and a simplified peak for $\mathrm{C}_{6}$ as expected. Irradiation of the resonance at $\mathrm{C}_{4} \cdot(3.78 \mathrm{ppm})$ collapsed signals at $C_{5}$ and $C_{3}$ to give a broad singlet for $C_{5}$ and a doublet for $C_{3}$. Finally irradiation of the hydrogens at $\mathrm{C}_{2}$ and $\mathrm{C}_{6}{ }^{\circ}(5.08 \mathrm{ppm})$ collapsed signals at $\mathrm{C}_{3} \cdot \mathrm{C}_{3}$. and $\mathrm{C}_{5}$ to give a singlet. a doublet. and a broad quintet respectively.

Intramolecular $\mathrm{S}_{\mathrm{V}} 2$ reaction of the 5'(S)-hy'droxy-6(S)tosylate phosphonate $\mathbf{5}$ with $\mathrm{K}_{3} \mathrm{CO}_{3}$ in acetone gave the desired $5^{\prime}(\mathrm{S})-6^{\prime}(\mathrm{R})$-epoxyphosphonate 6 in excellent yield. Chemical shifts for hydrogens at $C_{4}, C_{5}$. and $C_{6}$ changed noticeably from chemical shifts of 3.78 .4 .43 and $5.08 \mathrm{ppm}$ to $4.69,3.72$. and $3.04 \mathrm{ppm}$ respectively:

In summary. a new nucleoside epoxyphosphonate has been prepared from cytidine as an analog of the antibiotic fosfomycin in six steps in good yield. Its assignment and stereochemistry have been confirmed by NMR studies of compounds 4,5 and 6 , as well as a crystal structure of the mandelate ester shown in Figure 1. This synthetic 5'(S)$6^{\prime}(\mathrm{R})$-epoxyphosphonate 6 will be studied for its biological activity.

Acknowledgment. The authors are indebted to Prof. David F. Wiemer (University of Iowa. USA) for helpful discussion and experimental assistance. The authors also wish to thank Dr. Dale Swenson (University of Iowa. USA) for his help in carrying out the X-ray crystallographic analysis. This work has been supported by a grant from the Korea Science and Engineering Foundation (Grant R012001-000-00214-0)

\section{References}

1. (a) Glankowski. E. J.: Gal. G.: Purick. R.: Davidsont. A. I.: Sletzinger. M. J. Org. Chem 1970. 35.35lo (b) Springs. B: Haake. P. J. Ong Chem. 1976. 11, 1165. (c) Giordano. C. Castaldi, G. J. Org. Chem. 1989, 54. 1470. (d) Bandini, E.: Martelli, G.; Spunta, G.: Panunzio. M. Tetrahedon: Asmmeny 1995, 6. 2127. (e) Kitamura. M.: Tokunaga. M.: Noyori. R. $J$. Am. Chem. Soc. 1995. 117. 2931. (f) Iorga. B.: Eymery. F.: Savignac. P. Symtesis 1999. 2. 207. (g) Kobayashi. Y.: William. A. D.: Tokoro. Y. d. Org. Chent $2001,66,7903$.

2. Hendlin. D.: Stapley. E. O.: Jackson, M; Wallick, H; Miller. A. K. Wolf. F. J : Miller, T. W. Chaiet. L.: Kahan. F. M.: Foltz, E. L.: Woodruff. H. B.: Mata. I. M.: Hernandez. S.: Mochales. S. Science 1969. 166. 122

3. Inouye S.: Niizato. T.: Komiya. L.: Yuda. Y: Yamada. Y. Pham Ehn. $1982,5,941$.

4. (a) Inokawa. S.: Kawata, Y: Yamamota, K, Kawamoto. H.: Yamamoto. H.: Takagi. K.; Yamashita, M. Carboh d: Res. 1981. 88, 341. (b) Inokawa, S.: Yamamoto, H. Phosphonts Silfit 1983, 16, 79.

5. McEldoon. W. L.; Wiemer. D. F. Tetrahedron 1996. 52.11695.

6. Jung. K. Y.: Hohl. R. T.: Wiemer. A. J.: Wiemer. D. F. Bioorg. \& Hed Chem 2000. 8.2501.

7. (a) Kozlowski. .T. K.: Rath. N. P.: Spilling. C. D. Tetrahedron 1995. 51.6385. (b) Wroblewski, A. E; Piotrowska. D. G. Tetrahedhon: Annmetry 1999. 10. 2037.

8. This mandelate ester was erystallized from $\mathrm{CHCl}_{3}$ very slowly (about 2 months).

9. Crystal data for mandelate ester of diol 4: Empirical formula = $\mathrm{C}_{28} \mathrm{H}_{33} \mathrm{~N}_{3} \mathrm{O}_{12} \mathrm{P}, \mathrm{M} . \mathrm{W} .=758.95$, Crystal system = monoclinic. colorless plate, Volume $=1759.6(6) \AA^{3}$. Crystal size $=0.25 \times 0.13$ $\times 0.03 \mathrm{~mm} . \mathrm{F}(000)=792$. Density $=1.432 \mathrm{Mg} \mathrm{m} \mathrm{m}^{3}$. space group $=$ P2(1). Unit cell dimensions : $a=9.1150(14) . b=12.603(3) . c=$ $15.438(3) .\left(\alpha=90^{\circ}, \beta=97.174(7)^{\circ}, \gamma=90^{\circ}\right.$. Theta range $=2.1-20^{\circ}$. Absorption coefficient $=0.369 \mathrm{~mm}^{-1}$. Reflections collected $=$ 13716. Independent reflections $=3716$. Final $R$ indices $[I$ $2 \sigma$ (I)]: $R(R w)=0.0788(0.1630)$. Data was collected on a Nonius Kappa CCD diffractometer at $190(2) \mathrm{K}$ and refined with a full matrix least-squares on $\mathrm{F}^{2}$. 